\title{
Neither Physicians Nor Surgeons: Whither Neuropathological Skill in Post-war England?
}

\author{
ANNA KATHRYN SCHOEFERT** \\ Department of History and Philosophy of Science, University of Cambridge, \\ Free School Lane, Cambridge CB2 3RH, UK
}

\begin{abstract}
Neuropathologists constituted a small field in post-war England, perched between neurology, psychiatry, neurosurgery and pathology, but recognised as a discrete field of expertise. Despite this recognition, the success of the neighbouring fields of neurosurgery, psychosurgery and neurobiology, and the consultant status granted to pathologists in the National Health Service, neuropathologists struggled to stabilise their field. A discourse of skills, acquired and acquirable, became central to their attempts to situate the field in relation to surgeons' handicraft, physicians' diagnostic acumen and the technologies of the biological sciences.
\end{abstract}

Keywords: Neuropathology, Pathology, Physicians and surgeons, Skills, Specialities in the National Health Service

In November 1965 William Henry McMenemey took the stage at London's National Hospital to lecture on the past, present and future of the practice of neuropathology. He opened with reference to Thomas Willis' seventeenth-century Pathologiae Cerebri (published in English as An Essay of the Pathology of the Brain), but asserted that the neuropathologist as 'specialist investigator' was a 'product of the twentieth century'. 'A speciality emerges', he continued, 'because of the need to acquire new skills and explore new techniques rather than to take advantage of the opportunities for improved clinicopathological correlation and therapeutic appraisal which are made possible in a restricted field'. ${ }^{2}$

McMenemey's reference to Willis and the long history of neurology would have been a trope familiar to his audience, likely specialists associated with the National Hospital, an institution dedicated to nervous diseases and disorders. At mid-twentieth

\footnotetext{
* Email address for correspondence: aks63@cam.ac.uk I thank Nick Hopwood, Thomas Schlich, Nick Whitfield, Jim Connor, the participants at the 'History of Skill in Science and Medicine' workshop at McGill University, and Leon Rocha for commenting on earlier drafts; the three anonymous reviewers; Paul Weindling for remarks on émigré neuropathologists in Britain; Tilli Tansey and Caroline Overy for sharing their research on contemporary brain banking in Britain. A Gates Cambridge Trust doctoral scholarship and doctoral funding from the Arts and Humanities Research Council supported my research and writing up.

${ }^{1}$ W.H. McMenemey, 'The Practice of Neuropathology: Past, Present, and Future', The Lancet, 286, 7426 (1965), 1337-40: 1337.

2 Ibid;; Serge Duckett, 'William Henry McMenemey (1905-77)', Journal of Neuropathology and Experimental Neurology, 37, 4 (1978), 452-5; 'William Henry McMenemey', The Lancet, 310, 8050 (1977), 1239-40.
} 
century this would have included neurologists, neurosurgeons, neuropathologists, neuroradiologists, those in electro-encephalography and psychiatrists. These fields were merging, differentiating and reforming, as Stephen Casper, Delia Gavrus and others have elucidated. ${ }^{3}$ Neuropathologists' position in the professional structure, however, was unsteady, career paths were convoluted and the number of trainee and consultant posts in post-war England was too small to entice young physicians and surgeons to specialise in the field. ${ }^{4}$ This essay argues that McMenemey's remarks on a speciality emerging to acquire new skills were emblematic for practitioners keen to situate themselves between proficient surgeons and knowledgeable physicians.

This essay tracks an undercurrent of claims to skills through editorials, lectures, comments and textbooks on neuropathology in England, and Britain, after the Second World War. ${ }^{5}$ British neuropathologists' evocation of Willis' Pathologiae and pathologists' laments for a 'personal element' in the newly established National Health Service (NHS) chimed with Michael Polanyi's contemporaneous insistence on personal knowledge, tradition and apprenticeship. ${ }^{6}$ This essay, however, is not concerned with hidden rules of practice or tacit knowledge, though it draws from skills' intersections with historiographic categories of practices, material cultures and bodies; of rhetorics and identity; and of knowledge production. Instead, this essay examines neuropathologists' discourse of skill in relation to familiar debates about generalists and specialists, the art of the bed-side and the science of the laboratory. ${ }^{7}$ It argues that this discourse of skill provided a flexible framework within which a diverse set of practitioners moulded, claimed, declared outmoded, expanded, shifted and exploited claims to skill. The discourse positioned neuropathologists, like pathologists more generally, between the tropes of surgeons and

\footnotetext{
${ }^{3}$ The literature on mid-twentieth-century neurology, psychiatry, neurosurgery and allied fields is extensive. For excellent recent discussions: Stephen T. Casper, The Neurologists: A History of a Medical Speciality in Modern Britain, c1789-2000 (Manchester: Manchester University Press, 2014); Delia Gavrus, 'Men of Dreams and Men of Action: Neurologists, Neurosurgeons and the Performance of Professional Identity, 1925-50', Bulletin of the History of Medicine, 85, 1 (2011), 57-92; Mical Raz, The Lobotomy Letters: The Making of American Psychosurgery (Rochester, NY: University of Rochester Press, 2013).

${ }^{4}$ Ingrid Allen, 'The Changing Face of Neuropathology', in Peter Hall and Nicholas A. Wright (eds), Understanding Disease: A Centenary Celebration of the Pathological Society (Chichester: John Wiley and Sons 2006), 185-91; Jennian Geddes, 'From Treponemes to Prions: The Emergence of British Neuropathology', in F. Clifford Rose, Twentieth-Century Neurology: The British Contribution (London: Imperial College Press, 2001), 227-54 on twentieth-century British neuropathology. Histories concentrating on neuropathology and neuropathologists are rare, though the field and its practitioners feature in histories of neurology, psychiatry, neuroanatomy, neurosciences. This paper also points to significant intersections with histories of pathology: W.D. Foster, A Short History of Clinical Pathology (Edinburgh: Livingstone, 1961); George J. Cunningham, The History of British Pathology (Bristol: White Tree Books, 1992); Cay-Rüdiger Prüll, Medizin am Toten oder am Lebenden? Pathologie in Berlin und in London, 1900-45 (Basel: Schwabe, 2003); Russell C. Maulitz, 'Pathology', in Peter J. Bowler and John V. Pickstone, Cambridge Histories of Sciences, Vol. 6 Modern Life and Earth Sciences (Cambridge: Cambridge University Press, 2009), 367-82 for reference.

5 This essay concentrates on post-war England due to the remit of the 1946 National Health Service Act, which covered England and Wales. Welsh centres of neuropathology largely post-date the period addressed in this essay. Edinburgh and Glasgow had strong pathological and neuropathological traditions; health care structures, however, differed.

${ }^{6}$ Michael Polanyi, Personal Knowledge: Towards a Post-Critical Philosophy (London: Routledge, 1998 [1958]). One of Polanyi's exemplars for connoisseurship was the 'medical diagnostician's skills', an art of doing and knowing: idem, 54.

7 Scholarship on 'bed-side' and 'bench' medicine, and generalists and specialists, is rich, particularly for Britain, Christopher Lawrence, 'Science, Technology and the Clinical Art in Britain 1850-1914', Journal of Contemporary History, 20, 4 (1985), 503-20; Steve Sturdy, 'Looking for Trouble: Medical Science and Clinical Practice in the Historiography of Modern Medicine', Social History of Medicine, 24, 3 (2011), 739-57. Casper, op. cit. (note 3 ) on the rhetoric of generalist and specialist practice in neurology.
} 
physicians, and phrased (neuro)pathological expertise in terms which insinuated it into clinical medicine, medical science and biology alike.

To retrace neuropathologists' claims to skill, this essay introduces neuropathology and its practitioners in post-war England, noting its affiliations with pathology, neurology and psychiatry. It proceeds to explore claims to skill in the 1950s and 1960s debates on 'whither' pathology and neuropathology. It then turns to the example of brain banking, which became a new ideal site to practice neuropathology in the mid-1970s. ${ }^{8}$ The mid-twentieth-century concerns shown herein resonated for decades. The UK Health Department approved neuropathology as a full speciality only recently, in 2013; neuropathologists' disciplinary affiliations and the needs of a small speciality in the NHS continue to be debated. ${ }^{9}$

\section{Neuropathologists in post-war England}

McMenemey and his peers in neuropathology, neurology and cognate fields did not doubt that neuropathology constituted a distinct body of knowledge, the study of 'deranged function of the nervous system', as McMenemey would define it in $1965 .{ }^{10}$ For some this stretched back to early modern humoral theories of the nervous system, for others it dated to late-nineteenth-century histologists. ${ }^{11}$ Most would have agreed with McMenemey's fanciful description of a field 'sired by neurology plus psychiatry' and 'mothered by pathology'. ${ }^{12}$ In the 1950s and 1960s its practitioners were classifying tumours of the brain and the nervous system, thereby underpinning neurosurgery; analysing head injuries in traffic accidents, thereby mobilising public policy; and commenting on dementia and epilepsy, thereby reshaping boundaries between neurology and psychiatry. Controversies about somatic traces in schizophrenia continued to rage, while work in tissue culture, on kuru and scrapie, demyelinating diseases and encephalitis was defining new research subjects. ${ }^{13}$ The field, however, was small. Compared with more than 750 specialists in pathology and almost 100 neurologists practising in 1960s England, there were fewer than twenty-five full-time consultant posts allocated to neuropathology when McMenemey spoke in $1965 .{ }^{14}$

Into the 1960s the nervous system had remained largely inaccessible intra vitam except for in surgery, via the varying resolutions of X-rays and cerebral ventriculographs, by electro-encephalography or, by proxy, in patients' motor, reasoning and language abilities. Excluding biopsy studies of neurosurgically removed tissue and experimental research, neuropathologists still focused extensively on post mortem cases, which chafed

\footnotetext{
${ }^{8}$ Lionel Whitby, 'Whither Clinical Pathology? Trends and Opportunities', Journal of Clinical Pathology, 4, 2 (1951), 129-36; John Glaister, 'Whither Forensic Medicine?', BMJ, 2, 4782 (1952), 473-6.

${ }^{9}$ Announcement by the British Neuropathological Society, dated 9 December 2013, http://www.bns.org.uk/neu ropathology-as-a-specialty-in-the-uk/ (accessed 27 December 2014). Marc R. Del Bigio et al., 'Neuropathology Training Worldwide: Evolution and Comparisons', Brain Pathology, 24 (2013), 285-98.

${ }^{10}$ McMenemey, op. cit. (note 1), 1338.

11 Ibid., 1337. Alfred Meyer, 'Recent Trends in Neuropathology', Journal of Mental Science, 106, 445 (1960), 1181-92.

12 McMenemey, op. cit. (note 1), 1340.

13 Geddes, op. cit. (note 4).

14 Rosemary Stevens, Medical Practice in Modern England: The Impact of Specialization and State Medicine (New Haven: Yale University Press, 1966), 198; McMenemey, op. cit. (note 1), 1338. Disciplinary overlaps between neurologists, neuropathologists, pathologists and neurosurgeons complicate these tallies. Stevens' count of pathologists and neurologists included part-time consultants, honorary hospitals consultants with full-time university appointments and specialists employed in public laboratories. The numbers are nonetheless indicative of an order of magnitude.
} 
with mid-twentieth-century British pathologists who tended to investigate conditions in living patients. ${ }^{15}$ The nervous system post mortem offered up a dizzying variety of tissue and required lengthy preparation for study. Congruent with other neurological fields neuropathology was associated with particular, artisanal techniques. ${ }^{16}$ The silver impregnation to render neurons and dendrites visible, specialist stains to highlight cell bodies and the neuro-anatomical habit of embedding tissue in celloidin differed significantly from typical procedures in pathology. Links made between intra vitam states and post mortem findings were easily dismissed as artefacts of technique, accompanying illness, or death, lending the field an odd cast. Differences in tissue preparation, the field's 'mystique' and the unusual nomenclature contributed to most clinical pathologists 'prefer[ring]' to leave neuropathology to neuropathologists, McMenemey claimed. ${ }^{17}$

In the first post-war decade English neuropathologists constituted a small, diverse group. Many practitioners maintained multiple, loose associations with pathology, neurology and psychiatry. ${ }^{18}$ At least half gathered in the wider London area with its density of medical schools, specialist hospitals and research institutions, though neuropathologists also practiced in Manchester, Leeds, Sheffield, Oxford and other English hospitals and universities. ${ }^{19}$ In London, one set of practitioners clustered around Dorothy Russell at the London Hospital, where Russell held the professorship in morbid anatomy and directed the institute of pathology. ${ }^{20}$ She had trained first as a pathologist, specialising in neuropathology in order to collaborate with the neurosurgeon Hugo Cairns in the late 1920s. If Russell stood for the alliances between neuropathology and general pathology, and neuropathology and neurosurgery, J. Godwin Greenfield at the National Hospital and McMenemey at the Maida Vale Hospital exemplified the long-standing connections between neurology and neuropathology. Around 1950, Greenfield was a lionised figure. He had been at Queen Square almost continuously since 1912 and was widely considered the 'Dean of Neuropathologists' for his many years as dean of the National Hospital and his influence on a generation of neuropathologists, neurologists and neurosurgeons in England and abroad. ${ }^{21}$

${ }^{15}$ Prüll, op. cit. (note 4).

16 Techniques and practices have been central to histories of neurology, neuro-anatomy and the neurosciences. Tara H. Abraham, 'Transcending Disciplines: Scientific Styles in Studies of the Brain in Mid-Twentieth Century America', Studies in History and Philosophy of Biological and Biomedical Sciences, 43, 2 (2012), 552-68; Cornelius Borck, 'Between Local Cultures and National Styles: Units of Analysis in the History of Electroencephalography', Comptes Rendus Biologies, 329, 5-6 (2006), 450-59; Katja Guenther, 'Recasting Neuropsychiatry: Freud's "Critical Introduction" and the Convergence of French and German Brain Science', Psychoanalysis and History, 14, 2 (2012), 203-26; Michael Hagner, 'Cultivating the Cortex in German Neuroanatomy', Science in Context, 14, 4 (2001), 541-63; Heini Hakosalo, 'The Brain under the Knife: Serial Sectioning and the Development of Late Nineteenth-Century Neuroanatomy', Studies in History and Philosophy of Biological and Biomedical Sciences, 37 (2006), 172-202; Edwin Clarke and L.S. Jacyna, Nineteenth-Century Origins of Neuroscientific Concepts (Berkeley: University of California Press, 1992); Frank W. Stahnisch, 'Making the Brain Plastic: Early Neuroanatomical Staining Techniques and the Pursuit of Structural Plasticity, 1910-70', Journal of the History of the Neurosciences, 12 (2003), 413-35.

${ }^{17}$ McMenemey, op. cit. (note 1), 1337.

18 Stephen T. Casper, 'One Hundred Members of the Association of British Neurologists: A Collective Biography for 1933-60', Journal of the History of the Neurosciences, 20, 4 (2011), 338-56.

${ }^{19}$ W.H. McMenemey, 'Neuropathology in Western Europe: Part II: Great Britain', Journal of Neuropathology and Experimental Neurology, 18, 4 (1959), 645-6.

${ }^{20}$ Jennian F. Geddes, 'A Portrait of "The Lady": A Life of Dorothy Russell', Journal of the Royal Society of Medicine, 90 (1997), 455-61. Allen, op. cit. (note 4), 187-8.

${ }^{21}$ Webb Haymaker, 'J. Godwin Greenfield, MD: A Neuropathologist's Appreciation and a Bibliography', Archives of Neurology and Psychiatry, 80, 5 (1958), 590-6: 590. 'Joseph Godwin Greenfield', http://munksro 11.rcplondon.ac.uk/Biography/Details/1887 (accessed 27 December 2014). 
A third strand of neuropathology was embodied in Alfred Meyer at the Maudsley Hospital, a hospital dedicated to psychiatry. Meyer was a German-born psychiatrist who had trained in neuropathology under the renowned Walther Spielmeyer in Munich. ${ }^{22}$ In the 1930s Meyer had been one of many German psychiatrists and neuropathologists to flee Germany and continental Europe, and one of several émigré psychiatrists to receive Rockefeller Foundation funding to settle in England. ${ }^{23}$ He was thought of as an emissary of the German model of clinical psychiatry, in which neuropathology was understood as one of psychiatry's 'auxiliary sciences' ${ }^{24}$ For the director of the Maudsley he combined a clinician's understanding of 'real problems' in psychiatry with expertise in the natural sciences. $^{25}$ It was a compliment that would resonate with British neuropathologists throughout the mid-twentieth century.

Together with Elisabeth Beck, another German émigré, Meyer would shape a generation of neuropathologists keen to explore the intersection of psychiatry and neuropathology. ${ }^{26}$ Among Meyer's trainees was John Arthur Nicholas (Nick) Corsellis, whose career path revealed the post-war hopes for neuropathology. ${ }^{27}$ Corsellis was appointed a trainee neuropathologist at Runwell Hospital, a large mental hospital just east of London, in 1947. The appointment was largely prospective; the hospital's superintendent Rolf StrömOlsen hoped to establish a department of neuropathology in the coming years. Founded in the inter-war period, Runwell was an unusual psychiatric hospital in employing researchers in biochemistry, psychology, electro-encephalography - and neuropathology. Only the Maudsley, the Burden Neurological Institute in Bristol and psychiatric hospitals in Chichester and Dumfries in Scotland had similar provisions, though Ström-Olsen was not the only mid-twentieth-century superintendent to encourage neuropathology in

\footnotetext{
22 N.C., 'Alfred Meyer, Professor Emeritus of Neuropathology in the University of London', The Psychiatrist, 15 (1991), 247-8. Alfred Meyer, 'Early Professional Reminiscences', Neuropathology and Applied Neurobiology, 14 (1988), 431-42.

${ }^{23}$ Uwe Hendrik Peters, 'The emigration of German psychiatrists to Britain', in German E. Berrios and Hugh Freeman (eds), 150 Years of British Psychiatry: Vol. 2: The Aftermath (London: Athlone, 1996), 564-80; Jürgen Peiffer, 'Die Vertreibung deutscher Neuropathologen', Der Nervenarzt, 69 (1998), 99-109; Paul Weindling, 'An Overloaded Ark? The Rockefeller Foundation and Refugee Medical Scientists, 1933-45', Studies in History and Philosophy of Biological and Biomedical Sciences, 31, 3 (2000), 477-89; Katherine Angel, Edgar Jones and Michael Neve (eds), European Psychiatry on the Eve of War: Aubrey Lewis, the Maudsley Hospital and the Rockefeller Foundation in the 1930s (London: Wellcome Trust Centre for the History of Medicine at the University College London, Medical History Supplement 22, 2003); Volker Roelcke, Paul J. Weindling and Louise Westwood (eds), International Relations in Psychiatry: Britain, Germany, and the United States to World War II (Rochester, NY: Rochester University Press, 2010); Paul J. Weindling, 'Alien Psychiatrists: British Assimilation of Psychiatric Refugees, 1930-50', in idem, 218-35.

${ }^{24}$ Eric J. Engstrom, Clinical Psychiatry in Imperial Germany: A History of Psychiatric Practice (Ithaca, NY: Cornell University Press, 2013).

${ }^{25}$ Letter, Edward Mapother to Daniel O’Brien, 10 October 1933, Folder 42, Box 4, Series 1.1, Record Group 6.1, Field Offices, Paris, Rockefeller Foundation records, Rockefeller Archive Centre.

26 J.B. Cavanagh, 'Obituary: Elisabeth Beck (1907-2002): an Appreciation', Neuropathology and Applied Neurobiology, 20 (2004), 193. In the decade immediately after the Second World War, Meyer and Beck trained Nick Corsellis, Sabina Strich, Leonard Frome, Ronald Norman, Denis Leigh and James Brierley, among others.

${ }^{27}$ Burkhard S. Kasper et al., 'Neuropathology of Epilepsy and Psychosis: The Contributions of JAN Corsellis', Brain, 133 (2010), 3795-805; J.T.L. Birley, 'Professor J.A.N. Corsellis (Introduced by Dr J.L.T. Birley on Behalf of Professor W. A. Lishman)' in 'The Eighteenth Annual Meeting, 1989', Psychiatric Bulletin 13 (1989), 709-14: 713-14; T.J. Crow, 'J.A.N. Corsellis 1915-94', Psychiatric Bulletin, 20, 9 (1996), 508-9; T.J. Crow, 'Jan Corsellis', The Lancet, 344, 8934 (1994), 1426.
} 
psychiatric settings. ${ }^{28}$ There were, moreover, nineteenth- and early twentieth-century precedents at the West Riding Asylum in Wakefield or the London County Council's Claybury Asylum. ${ }^{29}$ These earlier asylum laboratories, however, had had wide remits from identifying infectious diseases to performing autopsies. Ström-Olsen had more specific investigations in mind. A proponent of leucotomies and other psychosurgeries, he envisaged neuropathologists elucidating pre- and post-operative states based on a study of leucotomised tissue and brains post mortem. ${ }^{30}$ At the time of his appointment Corsellis already had a background in psychiatry. To train in neuropathology he was sent first to the Southend General Hospital to further his knowledge of morbid anatomy, then seconded to the Maudsley to study under Meyer. ${ }^{31}$

Corsellis' Runwell appointment mapped onto large-scale re-organisation of medical services. Regional hospital boards were consolidating psychiatric, voluntary and general hospitals. The new health system maintained some arrangements of the war-time Emergency Public Health Laboratories which had co-ordinated blood donations, infectious disease tests and other services. ${ }^{32}$ In the new North-East Thames Metropolitan region of hospitals, Corsellis' laboratory was one of the few, if not the only, laboratory sites dedicated to examining the tissue and organs of the nervous system. The stated reciprocity between psychiatric hospitals and general hospitals opened his laboratory to practitioners in the region. In the coming decade, Corsellis would provide regional hospitals and coroners with post mortem diagnoses of brains and nervous tissue, examining some 120 to 270 brains a year. ${ }^{33}$ The work on biopsied tissue and attendant research that Runwell's superintendent anticipated, however, never materialised. The number of psychosurgeries rapidly peaked and then declined in the first decade after the Second World War. ${ }^{34}$ Neurosurgery, however, was flourishing and collaborations between neurosurgery and

${ }^{28}$ In 1933 the superintendent at Stoke Park Colony in Bristol had encouraged Ronald Norman to open an on-site neuropathological laboratory: W. Blackwood, 'Ronald Melville Norman M.D., F.R.C.P., D.P.M', Acta Neuropathologica, 12, 2 (1969), I-II. See also Leonard Crome, appointed to Fountain Hospital in Tooting in 1956: S. Duckett and J. Stern, 'Obituary: L. Crome', Neuropathology and Applied Neurobiology, 27 (2001), 406-7.

${ }^{29}$ Geddes, op. cit. (note 4); Allen, op. cit. (note 4). Michael Anthony Finn, 'The West Riding Lunatic Asylum and the Making of the Modern Brain Sciences in the Nineteenth Century' (unpublished PhD thesis: University of Leeds, 2012); Tatjana Buklijas, 'The Laboratory and the Asylum' (unpublished MPhil thesis: University of Cambridge, 1999); contributions in 'Lunacy's Last Rites: Dying Insane in Britain, c1629-1939', History of Psychiatry, 23, 1 (2012); Alfred Meyer, 'Frederick Mott, Founder of the Maudsley Laboratories', British Journal of Psychiatry, 122, 576 (1973), 497-516; Rolf Ström-Olsen, 'Some Problems in the Study of Psychotic Illness', Journal of Mental Science, 106, 444 (1960), 803-14: 803-6.

${ }^{30}$ Ström-Olsen, op. cit. (note 29), 809; idem cited in J.M. Tanner, Prospects in Psychiatric Research: The Proceedings of the Oxford Conference of the Mental Health Research Fund (Oxford: Blackwell Scientific Publications, 1953); A.H.G., 'R Strom-Olsen', BMJ, 293, 6559 (1986), 1447.

31 'County Boroughs of East Ham and Southend on Sea: The Tenth Annual Report of Runwell Hospital: For the Year 1946', 12; Kasper, op. cit. (note 27).

${ }^{32}$ Foster, op. cit. (note 4).

${ }^{33}$ For patient numbers, deaths among in-patients and number of brains received from other regional sites, see Runwell's annual reports.

${ }^{34}$ John Pippard, 'Leucotomy in Britain Today', Journal of Mental Science, 108, 454 (1962), 249-55; Rolf Ström-Olsen and Sheila Carlisle, 'Bi-Frontal Stereotactic Tractotomy: A Follow-up Study of its Effects on 210 Patients', British Journal of Psychiatry, 188, 543 (1971), 141-54; Brianne M. Collins and Henderikus J. Stam, 'A Transnational Perspective on Psychosurgery: Beyond Portugal and the United States', Journal of the History of the Neurosciences, 23 (2014), 335-54. 
neuropathology productive. ${ }^{35}$ In parallel to scrutinising surgical specimens clinicians and researchers in 1950s England were situating neuropathology as critical for understanding schizophrenia, epilepsy and dementia, and studying demyelinating diseases, metabolic disorders or neuromuscular disorders central to the neurological canon. ${ }^{36}$

Corsellis' 1947 appointment reflected a certain momentum. The new 1949 Atlas of Neuropathology, co-authored by McMenemey, was trailed by a string of English-language publications. ${ }^{37}$ By the end of the 1950s Greenfield had published Neuropathology (later Greenfield's Neuropathology) with chapters by McMenemey, Meyer, William Blackwood and Ronald Norman; Russell had co-authored Tumours of the Nervous System with the neurosurgeon Lucien Rubinstein; and Greenfield and colleagues issued specialist books on neuromuscular diseases. ${ }^{38}$ It created a new English-language library of neuropathology, hitherto largely thought limited to German-, French- and Spanish-language tomes. ${ }^{39}$ Part of post-war disciplining efforts these textbooks drew up lineages and evoked questions of appropriate and necessary skills. Greenfield's Neuropathology thus designated a 'French school' of the anatomy and neurology of lesions and a 'German school' of the histopathology of nervous cells. His genealogy suggested notions of craftsmanship that passed a rich 'technical armamentarium' from master to disciple. ${ }^{40}$ Importantly, clinical and technical schools overlapped. Alois Alzheimer, Franz Nissl and other German histopathologists, whom Greenfield praised, were equally well known for their clinically orientated research as for their intricate staining regimens and painstaking observations. Greenfield contended that neuropathologists needed to be 'not only pathologists but also anatomists and to some extent clinical neurologists and psychiatrists ... [familiar with] the history and details of the patient's illness'. ${ }^{41}$ They were to combine the skills of clinicians and the skills of technicians.

After Greenfield's death in 1958 his obituarists reprised his visions of an ideal neuropathologist. The Canadian neurosurgeon Wilder Penfield thus described him as a 'clinical pathologist rather than a cytologist aloof from bedside problems' ${ }^{42}$ Yet, Greenfield was prized equally for his adeptness as for his exceptional ability as consultant to colleagues. Obituarists remembered him as 'an extremely able general histologist', 'accomplished cabinet maker', a 'superb technician' and a 'true artisan', widely admired

\footnotetext{
35 See, for instance, Russell's long-standing partnership with Cairns or the group of Oxford neuropathologists surrounding Cairns. See also Kasper et al., op. cit. (note 27), 3797 on Corsellis' collaborations with neurosurgeons.

${ }^{36}$ Denis Leigh, 'Contributions of Neuro-anatomy and Neuropathology to Psychiatry', BMJ, 2, 4943 (1955), 815-8; 'Royal Society of Medicine: The Future of Neurology', The Lancet 265, 6855 (1955), 131-2; McMenemey, op. cit. (note 19).

37 W. Blackwood, T.C. Dodds, J.C. Sommerville, Atlas of Neuropathology (Edinburgh: Livingstone, 1949).

${ }^{38}$ Greenfield et al., Neuropathology (London: Edward Arnold, 1958); Dorothy S. Russell and Lucien J. Rubinstein, Pathology of Tumours of the Nervous System (London: Edward Arnold, 1959) was intended to be a chapter in Neuropathology, but was issued as a stand-alone volume; C. Coërs and A.L. Woolf, The Innervation of Muscle (Oxford: Blackwell Scientific Publications, 1959); J. Godwin Greenfield et al., An Atlas of Muscle Pathology in Neuromuscular Diseases (Edinburgh: Livingstone, 1957).

${ }^{39}$ Blackwood, Dodds, Sommerville, op. cit. (note 37); Dorothy Russell, Histological Technique for Intracranial Tumours (Oxford: Oxford University Press, 1939); Joseph Godwin Greenfield and E. Farquhar Buzzard, Pathology of the Nervous System (London: Constable and Co, 1921).

${ }^{40}$ J.G. Greenfield, 'General Pathology of the Nerve Cell and Neuroglia', in Greenfield et al., Neuropathology, op. cit. (note 38), 1-66: 1-4. Echoed in Meyer, op. cit. (note 11), 1185.

41 Greenfield, op. cit. (note 40), 2.

42 Wilder Penfield, 'Obituary: J.G. Greenfield, M.D. 1884-1958: Appreciation of the Man', Archives of Neurology and Psychiatry, 80, 5 (1958), 587-9: 587.
} 
for his judicious use of reagents, photographic equipment and microtome razors. ${ }^{43}$ Such encompassing craftsmanship was vital. Greenfield had always argued that literature reviews were insufficient to advance knowledge. ${ }^{44}$ His 'matchless legacy' of publications therefore was due to 'sticking to his microscope over many years', a neurologist averred. ${ }^{45}$ Mid-twentieth-century neuropathological skills were thus seen to be encapsulated in the 'keen eye, directed down the microscope' and the 'open door' for those seeking advice. ${ }^{46}$ This duality between learned interaction and technical proficiency, between the genius technician at the microscope and the consultants' consultant, shaped the discourse of skills in the $1950 \mathrm{~s}$.

\section{Delineating skills: whither pathology, whither neuropathology}

Delineating a speciality's skills and identity held a particular urgency because of patterns of remuneration in the NHS. Merit awards and salary levels were to reflect a specialist's 'responsibilities, experiences, and skill', the Spens Report had recommended. ${ }^{47}$ There were few formal certificates of specialisation in England, and speciality status was conferred in part by peer recognition. ${ }^{48}$ Defining skills was therefore crucial as regional hospital boards were scrambling to decide on the numbers of specialist posts required and medical societies were rushing to specify training needs. This was particularly true for a field that had recently gained consultant status: pathology, neuropathology's maternal side, as McMenemey had termed it. ${ }^{49}$

As a speciality, pathologists had benefited tremendously from the establishment of the NHS inasmuch as they could be appointed as consultants. The war-time success of the Emergency Public Health Laboratories scheme had demonstrated the wide-spread need for, and interest in, pathologists' services. In the NHS their laboratories were opening to a greater number of medical practitioners. Dangers loomed nonetheless, a 1951 presidential address to the Association of Clinical Pathologists detailed. ${ }^{50}$ Success had previously depended on personal relationships with consultants. Now, laboratories were being 'overwhelmed with routine work, much of it unintelligently demanded' ${ }^{51}$ 'The personal side of our particular craft', the Association's president Lionel Whitby asserted, was in danger of 'being submerged in the impersonality of the State' ${ }^{52}$ Once the 'personal element' was lost, warned Whitby, 'original work, proper thought, and also status' were tarnished. Pathology was in danger of 'degenerat[ing] to the mechanical level

43 John N. Cumings, 'J.G. Greenfield, MD BSc LLD Edinb, FRCP', Journal of Clinical Pathology, 11, 3 (1958), 281-2: 282. 'Obituary: J.G. Greenfield', BMJ, 1, 5070 (1958), 585-6. W.H. McMenemey, 'Foreword', in W. Blackwood, J.A.N. Corsellis (eds), Greenfield's Neuropathology, 3rd edn (London: Edward Arnold Publishers, 1976), vii-ix.

${ }^{44}$ Haymaker, op. cit. (note 21), 591.

45 Ibid., 592.

46 Dorothy Russell, 'Perspectives in Neuropathology', The Lancet, 280, 7251 (1962), 309-11: 309.

47 As cited in Glaister, op. cit. (note 8), 473.

48 George Weisz, Divide and Conquer: A Comparative History of Medical Specialization (New York: Oxford University Press, 2006), 164-87.

${ }^{49}$ Vanessa Heggie, 'Specialisation without the Hospital: The Case of British Sports Medicine', Medical History, 54, 4 (2010), 457-74; Peter Duncan, 'Failure to Professionalise, Struggling to Specialise: The Rise and Fall of Health Promotion as a Putative Specialism in England, 1980-2000', Medical History, 57, 3 (2013), 377-96 for alternate cases of specialisation in the NHS.

50 Whitby, op. cit. (note 8).

51 Ibid., 136. The critique of an unreflected clamouring for pathologists was likely directed towards general practitioners previously without access to laboratory services. Complaints about access continued in the 1950s.

52 Ibid., 129. 
of a technique', be it in histology or biochemistry of body fluids. ${ }^{53}$ These were tasks for skilled technicians, rather than specialist consultants. The statement insinuated that skills of pathologists extended beyond technical prowess and included clinical acumen that could be neither automated, mechanised, nor handed off to technicians.

Clinical pathologists faced a volume of samples that exceeded neuropathological caseloads many times: yet technique, original work and proper thought also preoccupied neuropathologists. Traditionally, the field had been characterised by highly particular histopathological techniques. When Greenfield and his peers founded the Neuropathological Club in London in 1950, most of the twenty-eight members were active in morbid anatomy or neuro-histology. ${ }^{54}$ The validity of this approach to studying the brain and nervous system, however, was being questioned. The first international conference on the 'histopathology of the nervous system', held in Rome in 1952, positioned the congress as 'a bit of an acid test for morphology' at a time of ever increasing interest in pathophysiology. ${ }^{55}$ The opening speaker pinned his hope on new techniques and new collaborations with researchers proficient in chemistry or physiology. He argued that if morphology did not develop new techniques, it was fated to remain nothing more than a useful diagnostic tool, thereby suggesting that routine services were insufficient to sustain a field. ${ }^{56}$

Defining a professional identity by prodigious knowledge or defining it by extraordinary skill retraced a long-standing characterisation of physicians as knowledgeable and surgeons as skilled. ${ }^{57}$ Neuropathologists, like clinical pathologists, sought to bridge encyclopaedic knowledge and technical prowess. Embodying both sides was to shield specialists from the dulling effects of routine. Practitioners planned to save the 'personal element' by committing to research, an expansion of knowledge. Programmatic papers in The Lancet on 'further advances in pathology', 'the future position of the pathologist in medicine' and 'the future of university pathology', published between 1950 and 1963, exhorted pathologists, if at all possible, to combine research with the more routine duties of teaching or diagnosis in order to ward off becoming rote technicians, mere hands analysing specimens. ${ }^{58}$

For neurologists and psychiatrists neuropathology was a familiar research tool. Since the late nineteenth century its clinicopathological correlations and case studies had been seen

\footnotetext{
53 Ibid., 136.

54 Among them: Greenfield, McMenemey, Russell, Corsellis, Meyer, Marion Smith, Peter Daniels, Lionel Wolman, Ronald Norman, Leonard Crome, James Brierley. The Club also welcomed some international members. For a partial list of members in 1951, see image caption: 'Second Meeting of the Neuropathological Club, Maudsley Hospital, London: June 1951', Neuropathology and Applied Neurobiology, 23,2 (1997), 155. The original image is in the Queen Square Archives, QSA/14061, http://www.queensquare.org.uk/archives (accessed 27 December 2014).

55 Matthew T. Moore, Archives of the International Congresses and Society of Neuropathology: 1952-77 (Philadelphia: Lea \& Febinger, 1978), 40.

56 Ibid:; Paul Glees, 'The First International Congress for the Histopathology of the Nervous System Rome, 1952', Experientia, 4 (1952), 160; Whitby, op. cit. (note 8), 129 for similar sentiment among British pathologists. 57 Christopher Lawrence, 'Medical Minds, Surgical Bodies: Corporeality and the Doctors', in Christopher Lawrence and Steven Shapin (eds), Science Incarnate: Historical Embodiment of Natural Knowledge (Chicago: University of Chicago Press, 1998), 156-201. See Delia Gavrus and Nicholas Whitfield in this issue on surgical skills.

58 Dorothy Russell, 'Further Advances in Pathology', The Lancet, 262, 6789 (1953), 771-3; W.H. McMenemey,

'The Future Position of the Pathologist in Medicine', The Lancet, 272, 7051 (1958), 841-4; G. Payling Wright,

'The Future of University Pathology: Requirements in London', The Lancet, 282, 7319 (1963), 1777-80.
} 
as the primary means of advancing knowledge about disease in psychiatry and neurology. ${ }^{59}$ Greenfield was emblematic again. He had advised many at the National Hospital on their doctoral research projects, and for years had been the most prolific presenter of research at the Association of British Neurologists. ${ }^{60}$ Some neurologists thus worried that splitting neuropathology from neurology portended over-specialisation. ${ }^{61}$ Their concerns were echoed by Russell and others who feared that segregating neuropathologists in specialist hospitals and neurosurgery centres, and thereby separating them from general pathology, risked endorsing esoteric hothouses. ${ }^{62}$ After two independent congresses of neuropathology, 1952 in Rome and 1955 in London, neurologists, neuroradiologists, neurosurgeons, neuropathologists, neurophysiologists and others gathered as one in Brussels in 1957 at the First International Congress of Neurological Sciences. The congress intended to create one 'neurological science' under the aegis of neurology. Francis Walshe, a British neurologist, spoke for many when he argued that all neurology was 'neuropathology' because it investigated diseases and disorders of the nervous system. ${ }^{63}$ To prevent future fissions, Walshe eschewed identifying neurological science with particular crafts. He instead proposed that neurologists approach their field with whichever 'skills of the laboratory, the operating theatre, and the clinic' they possessed, but work towards one body of knowledge. ${ }^{64}$ Walshe's call chimed with British pathologists' fears that only technicians defined themselves by specific skills. 'The research worker', Walshe announced, 'who is tied to a single technic too often becomes a technician, with all the intellectual limitations this implies. He does not think in terms of problems but in terms of machines. ${ }^{65}$ Skills thus sat awkwardly in these disciplinary projects.

Alfred Meyer's 1960 article on recent trends in neuropathology assuaged concerns about technique. ${ }^{66}$ Discussing the work of Jan Purkinje and other nineteenth-century microscopists he argued that they exhibited 'a remarkable gift for accurate and sober observation ... achieved by (compared with modern standards) primitive dissection techniques and without the use of staining methods' ${ }^{67}$ Terms such as 'gift', and later 'men of genius', implied certain innate abilities. His praise for earlier practitioners maintained genealogies, while his claims to 'genius' disentangled neuropathologists from particularities of technique. The 'keen eye' of neuropathologists was adaptable, Meyer showed.

Meyer devoted half his essay to analysing the 'changing scene' of neuropathology. $\mathrm{He}$ suggested that histochemistry, ultramicroscopy and microchemistry were 'transform[ing] the very fundament' of the field. ${ }^{68}$ It perturbed him greatly that many researchers on the nervous system had no contact with neuropathologists, and that, conversely,

\footnotetext{
${ }^{59}$ Engstrom, op. cit. (note 24).

${ }^{60}$ I thank one of the anonymous reviewers for pointing this out. Casper, Neurologists, op. cit. (note 3), 130.

61 'Meeting of the Chairmen of the National Committees', in Proceedings of the First International Congress of Neuropathology, Rome, September 8-13, 1952: Vol. 3 (Torino: Rosenberg and Selier [1954]), 709-12. Moore, op. cit. (note 55), 56-8.

${ }^{62}$ Russell, Rubinstein, op. cit. (note 38); Russell, op. cit. (note 58), 772 and a broader discourse rueing overspecialisation in post-war British medicine.

${ }^{63}$ Francis Walshe, 'Neurology at the Crossroads', Neurology, 8, 10 (1958), 796-8: 796; Walshe's comments in 'Royal Society of Medicine', op. cit. (note 36).

64 Walshe, 'Neurology at the Crossroads', op. cit. (note 63), 798.

65 Ibid.

${ }^{66}$ Meyer, op. cit. (note 11); A. Meyer, 'Neuropathology', Journal of Mental Science, 90, 378 (1944), 193-230.

${ }^{67}$ Meyer, op. cit. (note 11), 1183.

${ }^{68}$ Ibid., 1186.
} 
neuropathologists were often stuck 'patiently resolving controversies [and] filling gaps' ${ }^{69}$ This was routine work devoid of the 'personal element' that had also filled Whitby and other clinical pathologists with trepidation. To make 'fundamental contributions' neuropathologists needed to liaise with researchers in the basic sciences. Meyer proposed either joining an existing team or 'acquiring additional training in the one or other basic science according to ... personal propensities'. ${ }^{70}$ Again, Greenfield was seen as exemplary. 'Although he was firmly rooted in the classical past of his speciality', an obituarist, most likely Meyer, recalled, 'it was impressive to watch him recognise that a new era had commenced with the development of histochemical and ultramicroscopic methods'. ${ }^{71}$ In his appreciation of new methods Greenfield demonstrated that skills could be harnessed by extension. Meyer couched his call for action in emphasising that neuropathologists would 'not enter ... a team with empty hands'. ${ }^{72}$ They had 'the key to a wealth of morphological data, normal and abnormal, without which the chemical or physiological approach to the nervous system would remain in a vacuum'. They were therefore "custodian[s] of continuity and of a sound balance between the old and new' ${ }^{73}$ They bore vital knowledge, if not always the newest technique.

In pathology, practitioners sought to move beyond being mere hands. In neuropathology, practitioners wanted to break with a portrayal of the field as arcane tinkering. Technical skill was valued, but feared as limiting. An emphasis on clinical knowledge and the ability to act as 'consultant's consultant[s]' therefore combined with claims to innate foundations for skills and the malleability of skills. ${ }^{74}$ The skills and knowledge of the microscopists lay as much in the trained eye as in the trained mind that could turn to other problems. ${ }^{75}$ The two provided, neuropathologists claimed, an extraordinarily adaptable platform for future collaborations. Skills had granted access to hospital positions and mobilised support from allied disciplines. Knowledge would prevent practitioners from being replaced.

\section{'Past, Present and Future of the Practice of Neuropathology'}

McMenemey's paper on the past, present and future of neuropathology, with which this essay opened, reprised the binaries research/routine and skill/knowledge. It advocated specialisation, but exhorted neuropathologists to maintain their knowledge in general pathology, neurology and psychiatry. It praised clinicians' acumen while gesturing towards new techniques in the biological and physical sciences that neuropathologists could explore. McMenemey acknowledged established genealogies, noted historic ties to Thomas Willis' morbid anatomy, commended the contributions of physicians and superintendents of nineteenth-century English asylums to neuropathology, and swore fealty to Greenfield. Significant sections of the paper were given to discussing the teaching of neuropathology and the awkward positions neuropathologists occupied in the NHS and the universities. Neuropathology shared disciplinary histories with several rapidly differentiating fields. Unlike neurology and pathology, the speciality, however,

${ }^{69}$ Ibid., 1191.

${ }^{70}$ Ibid., italics in original.

71 A.M., 'Obituary: Dr J.G. Greenfield', The Lancet, 271, 7020 (1958), 596.

72 Meyer, op. cit. (note 11), 1191.

73 Ibid.

74 McMenemey, op. cit. (note 58), 844.

75 See discussions of 'trained judgement' in Lorraine Daston and Peter Galison, Objectivity (New York: Zone, 2007). 
did not lend itself to either private practice or commercialisation. Its routine work and research practices were often closely linked, but funded separately. Concerns about these unstable conditions for neuropathological practice and training came to a head in the 1960s.

In 1962 the Neuropathological Club reformed as the British Neuropathological Society. That year British pathologists succeeded in establishing a College of Pathologists, independent from the Royal College of Surgeons and the Royal College of Physicians. ${ }^{76}$ McMenemey had supported a new college, writing in 1958 that pathology had been 'slow to develop in England' in part 'because there was virtually no corporate life within the profession' ${ }^{77}$ At the time he noted that pathologists preferred associating with the Royal College of Physicians, because 'a knowledge of general medicine' was 'of more value to a pathologist than an acquaintance with anatomy and proficiency in surgical technique' ${ }^{78} \mathrm{He}$ reiterated Whitby's demand that pathologists should be 'trained observers' and 'investigators', rather than 'just another pair of hands', to which NHS strictures and the overburdening by routine work often reduced them. ${ }^{79}$ McMenemey posited that pathologists possessed not just technical and clinical, but also unusual administrative and collaborative skills. They had to negotiate with technicians, patients, consultants, hospital administrators, public health officials and general practitioners. If the Royal College of Physicians' examination scheme could not adapt to pathologists' practices at the bench, not the bed-side, pathologists should favour a new institution capable of accommodating, and defending, their specialist needs.

The new college recognised pathologists as an independent speciality, no longer either surgeons or physicians. It restructured relationships between sub-specialities and thereby altered the previously loose arrangements between neurology, psychiatry, neurosurgery and neuropathology. In examination schemes for membership of the college neuropathology became subsumed under histopathology. Candidates could be assessed with a 'slant' towards neuropathology only at the second stage of a two-part examination, which began with two years of studying histopathology. ${ }^{80}$ Clinicians in neurology, psychiatry and other non-pathological specialities could take the second stage of the examination, but the college nonetheless pressed neuropathology into line with histopathology and morbid anatomy. Cross-overs between neurology and neuropathology, psychiatry and neuropathology, typical in Greenfield's, Corsellis' and McMenemey's generations, became rarer in the coming decade.

McMenemey counted twenty-eight permanent posts dedicated to neuropathology in Britain in 1965, evenly split between university and hospital appointments. A committee on neurology of the Royal College of Physicians in London recommended doubling the number to serve neurologists and neurosurgeons adequately. ${ }^{81}$ Psychiatry was

\footnotetext{
76 The College of Pathologists merged two earlier professional organisations: the Association of Clinical Pathologists and the Pathological Society of Great Britain and Ireland, which represented academic pathologists: Cunningham, op. cit. (note 4); Foster, op. cit. (note 4); James C.E. Underwood, 'A Short History of the Royal College of Pathologists', in Peter Hall and Nicholas A. Wright (eds), Understanding Disease: A Centenary Celebration of the Pathological Society (Chichester: John Wiley \& Sons 2006), 129-36; Stevens, op. cit. (note 14), 336-45.

77 McMenemey, op. cit. (note 58), 841.

78 Ibid., italics AKS.

79 Ibid., 842.

${ }^{80}$ Denis N. Barron and Robert C. Curran, 'The Objectives and Functions of the Royal College of Pathologists', Human Pathology: A Clinicopathologic Quarterly, 4, 2 (1973), 149-50.

${ }^{81}$ Report referenced in 'Annotation: Too Few Neuropathologists', The Lancet, 292, 7583 (1968), 1383.
} 
by comparison hardly considered. Be it because of the drop in psychosurgeries, the shift in in-patient numbers, the restructuring of mental health services or changes in psychiatric practices: Corsellis' 1947 appointment had remained unusual despite the re-organisation of psychiatry and pathology in the NHS. McMenemey regretted this development. He hoped that increasing the number of neuropathologists associating with psychiatric hospitals would 'resuscitate the spirit of Wakefield', the site of one of the most successful laboratories of English neuropathology in the nineteenth century. ${ }^{82}$ A tally taken three years later, by the neuropathologist Marion Smith, however, also counted only one appointment in a psychiatric hospital. ${ }^{83}$ Three psychiatric hospitals had part-time neuropathologist posts and a few liaised with neuropathologists regularly. Even counting the three neuropathologists at the Maudsley whom Smith listed, but did not include among neuropathologists affiliated with psychiatric institutions, numbers were low. The dearth of collaborations between psychiatrists and neuropathologists reflected the general shortage of neuropathologists, which contributed to a 'vicious circle', an article in The Lancet stated. Under-staffed neuropathologists could not support clinicians adequately and clinicians 'in turn los[t] interest and fail[ed] to support the harassed neuropathologist in his attempt to improve his department'. ${ }^{84}$ Neuropathologists risked becoming ever more secluded. Smith had reported that more than a quarter of teaching hospitals with neurosurgical wards lacked a neuropathologist on staff. Less than a third of the nonteaching hospitals with neurosurgical wards made provisions for neuropathology. ${ }^{85}$ Some neurologists and psychiatrists doubted whether neuropathology should even still be taught to trainees in neurology and psychiatry. ${ }^{86}$

Smith and her peers were equally concerned about the number of permanent consultant posts and the number of trainee posts, remarking that the lack of job security deterred candidates from entering the field. Problematic too were the five-year long training and lengthy focus on general pathology, decreed by the College of Pathologists' examination scheme. Some correspondents to The Lancet implied that the field's dual interests in research and routine would always be difficult to integrate into the NHS. ${ }^{87}$ Concentrating on diagnoses, which was more in line with NHS requirements, risked recreating a field of 'skilled technicians' ${ }^{88}$ As Whitby's 1951 presidential address, 'Whither pathology?', had stated more than a decade earlier in discussing pathology's rise to specialist status:

\footnotetext{
${ }^{82}$ McMenemey, op. cit. (note 1), 1339. Finn, op. cit. (note 29) on Wakefield as the 'very model of the modern research school' in the brain sciences.

${ }^{83}$ Marion C. Smith, 'Distribution of Neuropathologists in Relation to Neurologists and Neurosurgeons', Proceedings of the Royal Society of Medicine, 61, 10 (1968), 1010-6, 1012-3. She noted twenty-eight fulltime and ten part-time neuropathologists, but also mentioned some 'ten general pathologists who do some neuropathology' and five senior neuropathologists in research positions, who performed some 'routine work' and consulted on some cases, whom she did not include in her tally. She showed that more than a third of all neuropathologists clustered in London. Of the 266 specialist posts in England and Wales she listed in the 'neurological field', thirty-four were in neuropathology, ninety-eight in neurology, seventy-four in neurosurgery, forty-five in neuroradiology and fifteen in electroencephalography: Ibid., 1011.

84 'Too Few Neuropathologists', op. cit. (note 81). The gendering of 'the' neuropathologist obscures the number of women in senior posts in the late 1960s including, but not limited to, Marion Smith, F. Dawn Bosanquet, Betty Brownell, Wendy Grant, Elisabeth Beck. Dorothy Russell had retired in 1960. A study of gender, and gendering, in twentieth-century pathology, and neuropathology, would be very fruitful.

85 Smith, op. cit. (note 83), 1012.

${ }^{86}$ Henry Miller, 'The Organization of Neurological Services and Neurological Training', Proceedings of the Royal Society of Medicine, 61, 10 (1968), 1004-10 which preceded Smith's paper.

${ }^{87}$ F.M.R. Walshe, '[Letters to the Editor:] Too Few Neuropathologists', The Lancet, 293, 7589 (1969), 314.

88 Ibid.
} 
In brief, it is of little use for us to clamour for specialist status . . if we do not personally justify that status in our everyday work and in our contributions to the advance of knowledge derived from the material which we handle.

Let us not leave our work to technicians and registrars, let us keep the personal element alive, the clinical opinion and the intelligent application of laboratory procedures to the understanding of the individual case; to wit, a modern physician. ${ }^{89}$

A decade later, the 1960s papers by McMenemey and Smith illustrated similar on-going concerns about 'whither neuropathology'.

\section{“"Natural” brain bankers'}

As reports and tallies called for more neuropathologists, articles, editorials and textbooks painted pictures of a new dawn of technological progress. New stains were rendering the end terminals of nerve cells visible and electron microscopy was showcasing subcellular structures. Tissue cultures, histochemical methods of enzyme staining and autoradiographic labelling were offering further means of analysing nervous fibres and tissues in research and routine. ${ }^{90}$ Textbooks, previously often sceptical about applications, now included sections on these methods. Journals and yearbooks celebrated advances in neuropathological knowledge and proclaimed a golden age. ${ }^{91}$

Corsellis, who had come of age as a neuropathologist in the first decade of the NHS, shared the vision of a new dawn. Throughout his career, Corsellis had combined routine examinations at Runwell with research and teaching in London. He had been receiving Medical Research Council (MRC) grants since 1956, first for projects on mental illness and aging, later for collaborations with researchers at the Maudsley, the Institute of Psychiatry and other London-based institutions. Around 1970, his research interests had turned to investigating the effects of boxing on the brains, though he was also studying automated cell counting and computerised image processing of nervous tissue. ${ }^{92}$ Since the mid-1950s he had held several academic positions at the Institute of Psychiatry, thereby exemplifying the combination of teaching, research and routine work envisaged by Meyer and McMenemey. ${ }^{93} \mathrm{He}$ was urging neuropathologists to move beyond analysing obscure conditions. In a 1972 editorial in Psychological Medicine he pushed his peers to leave their 'histological kitchens' for 'biologically oriented laboratories', postulating that 'the neuropathologist would prefer to be seen less as a morbid anatomist consumed by the phenomena of death' and 'more as a biologist [illuminating] nervous tissue, ... in order to find out more about how it works and what happens to its owner in the presence of disease'.$^{94}$ Echoing earlier comments by Meyer and McMenemey, he remarked on the potential for new collaborations. Meyer had presented neuropathologists as 'custodians of a wealth of morphological data', McMenemey labelled pathologists 'consultant's

\footnotetext{
${ }^{89}$ Whitby, op. cit. (note 8), 136.

${ }^{90}$ Gordon M. Shepherd, Creating Modern Neuroscience: The Revolutionary 1950s (Oxford: Oxford University Press, 2010); W. Maxwell Cowan, 'The Emergence of Modern Neuroanatomy and Developmental Neurobiology', Neuron, 20, 3 (1998), 413-26.

91 See, eg., Harry Martin Zimmermann (ed.), Progress in Neuropathology (New York: Raven Press, Heinemann Medical, 1971-); Neuropathology and Applied Neurobiology (1975-), the journal published by the British Neuropathology Society; W. Thomas Smith and J.B. Cavanagh (eds), Recent Advances in Neuropathology (Edinburgh: Churchill Livingstone, 1979-).

92 Kasper et al., op. cit. (note 27).

93 Corsellis was senior lecturer 1956-9 and professor 1976-9. He also had long-standing roles in the British Neuropathological Society, the International Society of Neuropathologists and the Royal College of Psychiatry: Kasper et al., op. cit. (note 27), Birley, op. cit. (note 27).

94 J.A.N. Corsellis, 'Neuropathology and Psychiatry', Psychological Medicine, 2, 4 (1972), 329-31: 329-30.
} 
consultant[s]'. In his editorial Corsellis reaffirmed neuropathologists' 'key position'. They constituted a 'bridge linking the clinical research workers with those neurobiologists who are interested in the chemical or microscopical study of the normal and abnormal human nervous system' ${ }^{95}$

This bridge had become steadily more appealing since the late 1950s. Firstly in the circulation of brain tissue related to kuru and other rare neurological cases between field stations and neurobiological laboratories, and secondly in findings that dopamine, noradrenaline, other chemical transmitters and enzymes were stable in brain tissue for some time post mortem. ${ }^{96}$ Human brain tissue post mortem therefore no longer appeared to be a 'half decomposed, dirty material', unworthy of biochemists' attention. ${ }^{97}$ The research programme on post mortem material was further substantiated when dopamine deficiency in patients suffering from Parkinson's disease translated into clinical treatment with L-DOPA that alleviated many Parkinsonian symptoms. A few British neurochemists took up related work, clustering around investigations of Alzheimer's disease, which resembled Parkinson's disease in some neuropathological respects. Presence could be determined by accepted post mortem criteria, so neuropathologists could ascertain whether a patient had suffered from the disease even without a detailed clinical history.

Neurochemists had little patient contact and limited access to the brains of deceased patients with Alzheimer's disease. Even researchers affiliated with neurological institutes struggled, because these institutions often specialised in rare disorders. Deaths of patients with Alzheimer's disease and other chronic conditions were uncommon in these settings. Corsellis' position in Runwell, his academic ties to the Maudsley and the Institute of Psychiatry, his long-standing, wide network of clinicians and his neuropathological expertise in dementias made him an exceptional collaborator. Beginning in 1971, he agreed to supply David Bowen, a young biochemist recently hired by the University of London's Institute of Neurology, with 'fresh human brains obtained within twenty-four hours of death from a variety of patients, including patients with senile dementia and other diseases', Bowen recalled. ${ }^{98}$ By the mid-1970s, Corsellis had established similar collaborations with Edward Bird, a researcher on Huntington's chorea at the University of Cambridge, and Timothy Crow, a researcher into schizophrenia at the MRC's new Clinical Research Centre in Northwick Park. Some brains stemmed from patients at Runwell Hospital; others had been forwarded to Corsellis by consultants in regional hospitals or by coroners; and some likely had reached researchers due to appeals published in The Lancet and other journals. ${ }^{99}$

\footnotetext{
95 Ibid., 331.

96 Warwick Anderson, The Collectors of Lost Souls: Turning Kuru Scientists Into Whitemen (Baltimore: Johns Hopkins University Press, 2008); H. Ehringer and O. Hornykiewicz, 'Verteilung von Noradrenalin und Dopamin (3-Hydroxytyramin) im Gehirn des Menschen und ihr Verhalten bei Erkrankungen des extrapyramidalen Systems', Klinische Wochenschrift, 38, 24 (1960), 1236-9; O. Hornykiewicz, 'The Discovery of Dopamine Deficiency in the Parkinsonian Brain', Journal of Neural Transmission, 70 (2006), 9-15.

${ }^{97}$ Oleh Hornykiewicz in Larry R. Squire (ed.), The History of Neuroscience in Autobiography: Vol. 4 (Amsterdam: Elsevier Academic Press, 2004), 240-81: 255.

${ }^{98}$ Interview with David Bowen in Robert Katzman and Katherine L. Bick, Alzheimer Disease: The Changing View (San Diego: Academic Press, 2000), 184. Bowen had just returned from a post-doctoral position at the University of Michigan, where Wallace Tourtellote had established the first brain bank; Cathy Gere, 'A Brief History of Brain Archiving', Journal of the History of the Neurosciences, 12, 4 (2003), 396-410.

${ }_{99}$ M. Baraitser et al., 'Letters to the Editor: Huntingdon's Chorea', The Lancet, 309, 8013 (1977), 702-3. Confirming patterns of tissue exchange, consent procedures, contact with patients and next-of-kin, standardisations would require detailed analysis and access to Runwell Hospital's laboratory day-books and patient records.
} 
Bowen, Crow and others were not the first medical professionals to receive brain tissue from or via Runwell, but the practice of regularly sending out human brains post mortem likely marked a reversal for Corsellis and the staff of Runwell's neuropathological laboratory, which up to the early 1970s likely mainly received nervous tissue. Shipping out brains shifted practices within autopsy suites and neuropathological laboratories. Tissue which could not be sent to neurochemists within twenty-four hours of death was frozen and shipped on dry ice to arrest tissue deterioration. ${ }^{100}$ As exchanges became more frequent, freezing became more routine. This required new equipment for autopsy suites and mortuaries, systems of notification and shipment, and standardised record-keeping and post mortem practices in participating laboratories - leading the MRC to organise several workshops on brain banking in 1976. ${ }^{101}$

As suppliers of tissue and diagnosticians Corsellis and other neuropathologists became the gate-keepers to neurochemical studies. ${ }^{102}$ They provided the study material and they decided whether it was appropriate for the study. They acted as arbiters, confirming whether patients had suffered from Huntington's disease, Alzheimer's disease or multiple infarcts. Their diagnoses therefore had the power to validate, or invalidate, a case within a certain study. Technical and administrative skills, knowledge and access to material permitted Corsellis and his peers to establish neuropathologists as central figures in neurobiological research on human post mortem brains to the degree that late twentieth-century neuropathologists asserted that neuropathologists were " "natural" brain bankers'. 103

Brain banking was a small field. In 1976, when the MRC hosted its workshops on brain banking, it was supporting seven brain collections in Britain. Only that of Corsellis was directed by a neuropathologist, though neuropathologists were involved in all seven 'centres for the collection, storage and dissemination of healthy and diseased human brain tissue as a means of facilitating research into a wide range of disorders of the central nervous system', as the MRC described the collections at the time. ${ }^{104}$ Brain banking had confirmed neuropathologists' role in biological laboratories, but did not expand the field. Young, newly trained neuropathologists still struggled to secure consultant positions. None was advertised between 1974 and 1978, and several remained vacant in the late 1970s as neuropathologists of Corsellis' generation retired. Institutions strained to find registrars. Reports noted that about one in six consultant positions was unfilled, and argued that the lack of stable job prospects kept medical professionals from seeking a specialisation in the field. ${ }^{105}$ These were familiar statements. Wielding existing skills in diagnosis and

${ }^{100}$ E.D. Bird and L.L. Iverson, 'Huntington's Chorea: Post-Mortem Measurement of Glutamic Acid Decarboxylase, Choline Acetyltransferase and Dopamine in Basal Ganglia', Brain, 97, 3 (1974), 457-72: 458.

101 The National Archives of the UK (TNA), FD 23/2328, 'MRC Workshop on Brain Banking: Minutes and Papers of 1st Meeting Held on 5th July 1976', meeting minutes for discussions on standardising brain banking procedures. See also TNA, FD 23/2329, 'MRC Workshop on Brain Banking: Minutes and Papers of 2nd Meeting Held on 25th October 1976; Subsequent Notes and Correspondence Concerning Possible Setting Up of a Brain Bank; Papers and Reports'.

102 Ibid:; David M. Bowen, Carolyn B. Smith and Alan N. Davison, 'Molecular Changes in Senile Dementia', Brain, 96, 4 (1973), 849-56 on Corsellis' gate-keeper function for Bowen and Bird.

103 C. Duyckaerts et al., 'A Brain Bank in a Neuropathology Laboratory (With Some Emphasis on Diagnostic Criteria)', in F.F. Cruz-Sánchez and Eduardo Tolosa (eds), How to Run a Brain Bank: Journal of Neural Transmission Supplementum vol. 39, (1993), 107-18: 117.

104 TNA, FD 23/2328, op. cit. (note 101), file note, dated 11 July 1977. Gere, op. cit. (note 98) on differences between brain archives and brain banks.

105 TNA, MH 149/1773, 'Staffing in Neuropathology', regarding neuropathology consultant shortages in the 1970s; TNA, FD 23/4321, 'Neuropathology: Papers, Notes and Correspondence Concerning a Review of Current Research, Journal Articles and Publications' on similar concerns in the 1980s. 
microscopy, Corsellis and other brain bankers had cemented their place in natural sciences, but failed to stabilise the medical speciality in the 1970s. It was secure within the strictures of the NHS insomuch as there were dedicated posts, but the field was so small that a balance of practitioners was difficult to maintain.

\section{Conclusion}

In the discourse of skills that animated mid-twentieth-century English, and British, neuropathology, acknowledging and specifying existing skills was crucial in rallying the field. Skills were deeply implicated in the disciplinary histories that not only legitimised the field as a speciality, but also enculturated a diverse group of practitioners. Historical actors described craftsmanship in preparing tissue, exactitude and diagnostic expertise as key skills in neuropathology in order to highlight neuropathologists' resemblances with surgeons and physicians. The skills needed to analyse pathological states and disease processes of the nervous system also positioned neuropathology among the biological sciences.

In parallel to recouping, bolstering and transmitting traditions, William McMenemey, Alfred Meyer and Nick Corsellis sought to distance neuropathology from a sole focus on morbid anatomy and morphology. Here too, they mobilised narratives of skills, presenting neuropathology as a field perched almost on the brink whose future depended on acquiring new skills and new collaborators. Contemporaneous disciplinary developments in pathology and the patient-focused structure of the NHS, however, limited the reach of this vision. Acquiring and practising skills, while residing in the interstices between several medical fields, remained a difficult proposition. Defining a discipline by skills nonetheless supported flexibility in practice and saw neuropathologists advising neurosurgeons, neurologists, coroners, neurobiologists, as well as neurochemists. It placed them equally in clinical settings and university-based research laboratories.

Success in situating neuropathologists as custodians of the old and the new, and thereby as " "natural" brain bankers', showcased the entanglement of old and new skills. Neuropathologists' new positions in an emergent site of biomedical research, the brain bank, relied on long-established skills of diagnosis and co-operation. Innovative research projects ran alongside brain banking activities, but much of Corsellis' daily practice of brain banking, even in the 1970s, would have been familiar to neuropathologists in earlier decades. 'Recent advances in neuropathology have depended in part on new knowledge acquired in neurobiology, virology and cytochemistry, for which new techniques, often complicated and expensive, have been evolved', wrote McMenemey in his foreword to the third edition of Greenfield's Neuropathology in 1976, '[b]ut ... [t] the working tool of the neuropathologist is still the light microscope.' ${ }^{106}$

These disparate strands of mid-twentieth-century English and British neuropathologists' discourse about skill make clear the insistence on seeing skills as personal and embodied. Neuropathologists possessed and mastered 'their' skills. They conceived them to be transferable and flexible, both deployable properties and useful rhetorical devices. The familiarity of skills expressed and implied may encourage scholars to treat them as a monolithic category, but tracing neuropathologists' accounts reveals the productiveness of historicising skills. Here it elucidates anxieties about the interplay between science and medicine, and the troubles facing interstitial medical disciplines in the NHS.

${ }^{106}$ McMenemey, op. cit. (note 43), ix. 